\title{
43. AGE AND ORIGIN OF DACITE BOULDER CONGLOMERATE ANOMALOUSLY NEAR THE JAPAN TRENCH
}

\author{
George W. Moore, U.S. Geological Survey, Menlo Park, California \\ and \\ Kantaro Fujioka, Ocean Research Institute, University of Tokyo, Tokyo, Japan
}

\begin{abstract}
Dating of a hornblende concentrate by the ${ }^{40} \mathrm{Ar} /{ }^{39} \mathrm{Ar}$ method gives an age of $23.4 \pm 5.5 \mathrm{~m}$.y. for a dacite boulder from conglomerate in Deep Sea Drilling Project Hole 439. The conglomerate clasts range up to 1 meter in diameter and are nearly monolithologic, suggesting that a nearby former volcano erupted the dacite. The dacite is only $90 \mathrm{~km}$ landward from the Japan Trench, whereas modern trench-related volcanoes lie at least $120 \mathrm{~km}$ from their trenches. The dacite locality is on strike with and is probably an extension of a magmatic arc on the island of Hokkaido that crosses the Kuril arc at an angle of $65^{\circ}$ and which was active 16 to $36 \mathrm{~m}$.y. ago. The part of the former arc landward from the Kuril arc argues against an origin from a leaking subduction zone or from subduction of an active spreading ridge. The part seaward both from the Kuril and Japan arcs weakens an explanation based on migration of a trench-trenchtrench triple junction. The magmatic rocks probably formed along a middle-Tertiary plate boundary that had stepped seaward from a more-landward Cretaceous position. Later, the boundary stepped farther seaward at the Kuril arc and landward again at the Japan arc. If so, the present Japan subduction zone must have consumed most of the strata that had accumulated between it and the earlier trench.
\end{abstract}

\section{INTRODUCTION}

About $150 \mathrm{~km}$ off the east coast of northern Japan (Figure 1), drilling at DSDP Site 439, after penetrating approximately 1100 meters of nearly flat-lying Quaternary to middle-Tertiary strata, passed through about 50 meters of dacitic boulder conglomerate. The conglomerate contains boulders up to about 1 meter in diameter, many of which are angular. The boulders are nearly monolithologic, which along with the large size of the clasts suggests that they were erupted from a nearby volcano. If this is so, the volcanic rocks require a special explanation, because the site is only $90 \mathrm{~km}$ from the present Japan Trench, and modern trench-related volcanoes lie at least $120 \mathrm{~km}$ from their trenches (Dickinson, 1973). For example, the presently active volcanoes of northern Japan are about $300 \mathrm{~km}$ from the Japan Trench.

Earthquake foci indicate that the downgoing slab now lies about $15 \mathrm{~km}$ below Site 439 . The boulder conglomerate rests on an unconformity that has been cut on folded, flysch-like Upper Cretaceous rocks. Near the site, lithologic details within the Upper Cretaceous rocks are obscure on reflection profiles (Figure 2). However, about $50 \mathrm{~km}$ farther seaward, at the upper trench slope, where greater water depth eliminates interference from multiple reflections, the folded rocks below the unconformity are underlain by a conspicuous, gently dipping reflector, which lies about 1 second (two-way travel time) below the top of the Upper Cretaceous rocks, and 1.5 seconds above the reflector thought to be oceanic crust that can be traced from below the trench. The reflector underlying the folded Upper Cretaceous strata may be an old layer of oceanic crust that is now part of the upper plate at the Japan subduction zone. Mesozoic strata seem to thin from Site 439 to this place, and to wedge out entirely at about the middle of the trench slope.

To help explain the anomalous location of the volcanic rocks, we needed to learn their precise age, so that the time of eruption could be related both to correlative onshore magmatism and to plate-tectonic events. The small size of available core samples dictated that the ${ }^{40} \mathrm{Ar} /{ }^{39} \mathrm{Ar}$ dating method be used, and because some parts of the rock show evidence of alteration to clay, we chose to date a hornblende mineral separate.

\section{PETROLOGY AND CHEMISTRY}

The center of a dacite boulder $68 \mathrm{~cm}$ in diameter provided the sample for age determination (Figure 3 ). This boulder is one of the largest of those penetrated. The rock is slightly altered and is strongly porphyritic. The phenocrysts consist chiefly of plagioclase, which is strongly zoned, and of hornblende, usually euhedral or subhedral, and surrounded by an altered rim. The groundmass, which has an intersertal texture, consists 


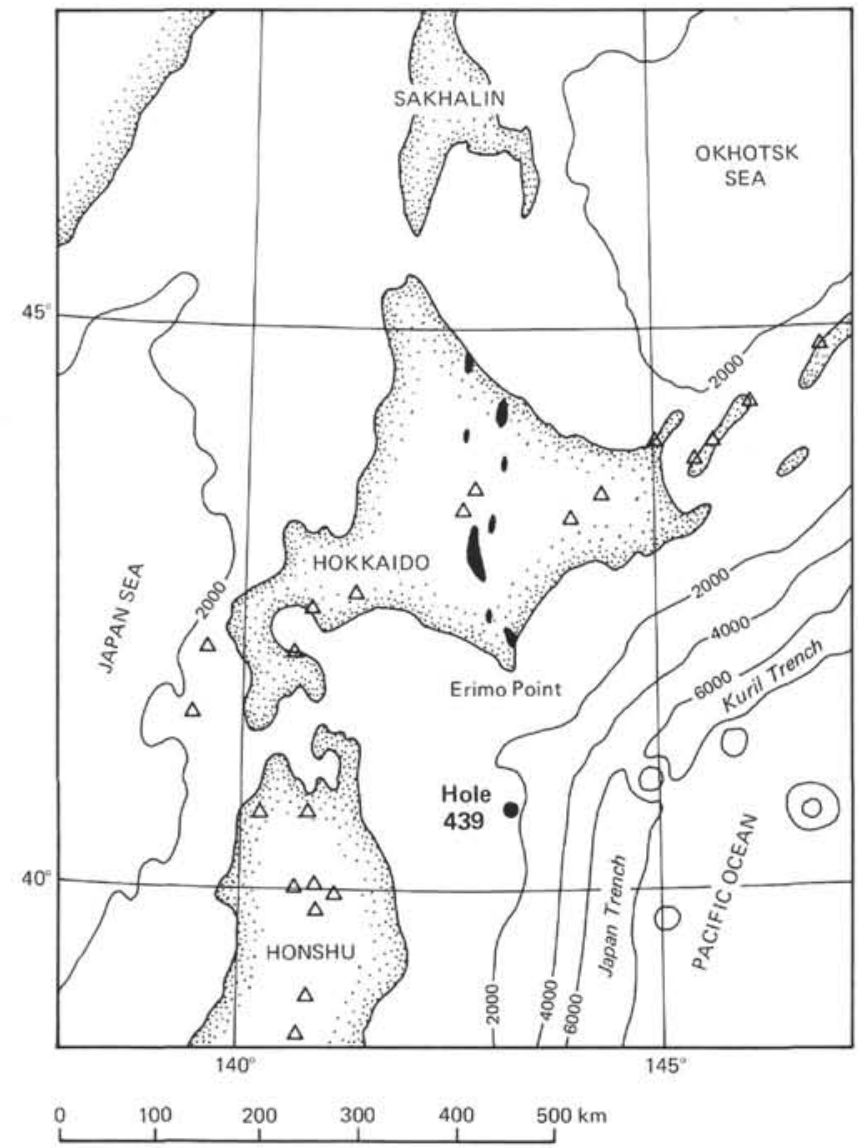

Figure 1. Location of DSDP Hole 439, which penetrated middle-Tertiary dacite conglomerate, showing relation to the Japan Trench, to middle-Tertiary plutons on Hokkaido (solid areas), and to active volcanoes (triangles).

of plagioclase, potassium feldspar, quartz, and glass that has been altered to aggregates of clay minerals. Thin-section study shows that the cores of the hornblende phenocrysts are relatively fresh.

The interior of the boulder is darker than morealtered $5-\mathrm{cm}$ rinds at the top and bottom. The dacite has a fairly uniform composition, and the rock is high in aluminum, probably at least in part because of the abundant plagioclase phenocrysts (Table 1). A chemical analysis of the upper altered rind (Table 1, 99-101 cm) shows a reduction in iron and magnesium and an increase in aluminum from values for the other, lessaltered samples from the interior of the boulder.

The interval from 123 to $139 \mathrm{~cm}$ in Section 439-34-2, at a depth of 1118 meters below the sea floor, was selected for hornblende separation and age determination. Hornblende from near that interval at the center of the boulder contains an average of 0.16 per cent potassium (Table 2, 120-122 cm).

\section{AGE DETERMINATION}

The hornblende for age determination came from a $16-\mathrm{cm}$ length of a quarter of the $7-\mathrm{cm}$ core. D. H. Sorg,
U.S. Geological Survey, crushed the core sample and concentrated the hornblende with a vibrating magnetic separator and a centrifuge containing heavy liquids. The concentrate weighed 0.17 grams, had a size range of 0.07 to $0.11 \mathrm{~mm}$, and a density of 3.05 to $3.12 \mathrm{~g} / \mathrm{cm}^{3}$. The color of the dry hornblende concentrate was olive black (5 YR 2/1).

E. S. Sims and J. C. von Essen, U.S. Geological Survey, determined the age of the hornblende concentrate under the direction of G. B. Dalrymple, using the totalfusion ${ }^{40} \mathrm{Ar} /{ }^{39} \mathrm{Ar}$ technique (Dalrymple and Lanphere, 1971). During irradiation by fast neutrons from ${ }^{238} \mathrm{U}$ in the core of the Geological Survey's Denver reactor, samples of a monitor mineral of known age adjacent to the unknowns provided a neutron-flux factor for the run. The method employs constants and correction factors for the decay of ${ }^{40} \mathrm{~K}$, for the ${ }^{40} \mathrm{Ar}$ content of air, and for interfering argon isotopes produced by calcium and potassium, as follows:

$$
\begin{aligned}
& \lambda, \text { decay constant of }{ }^{40} \mathrm{~K}=5.544 \times 10^{-10} \mathrm{yr}^{-1} \\
& C_{1},\left({ }^{40} \mathrm{Ar} /{ }^{36} \mathrm{Ar}\right)_{\text {air }}=295.5 \\
& C_{2},\left({ }^{36} \mathrm{Ar} /{ }^{37} \mathrm{Ar}\right)_{\mathrm{Ca}}=(2.72 \pm 0.014) \times 10^{-4} \\
& C_{3},\left({ }^{40} \mathrm{Ar} /{ }^{39} \mathrm{Ar}\right)_{\mathrm{K}}=(0.0059 \pm 0.00042) \times 10^{-4} \\
& C_{4},\left({ }^{39} \mathrm{Ar} /{ }^{37} \mathrm{Ar}\right)_{\mathrm{Ca}}=(6.33 \pm 0.043) \times 10^{-4}
\end{aligned}
$$

After the extraneous short-lived radioactive isotopes had decayed, the sample was fused, and a mass spectrometer analyzed the purified argon. The analytical data are as follows:

$$
\begin{aligned}
& A,{ }^{40} \mathrm{Ar} /{ }^{39} \mathrm{Ar}=23.95 \\
& B,{ }^{36} \mathrm{Ar} /{ }^{39} \mathrm{Ar}=0.0817 \\
& D,{ }^{37} \mathrm{Ar} /{ }^{39} \mathrm{Ar}=29.00 \text { (corrected for }{ }^{37} \mathrm{Ar} \text { half-life, } \\
& 35.1 \text { days) }
\end{aligned}
$$$$
J \text {, neutron-flux factor }=0.00596
$$

Using the relationship

$$
t=\frac{1}{\lambda} \ln \left(1+J \frac{A-C_{1} B+C_{1} C_{2} D-C_{3}}{1-C_{4} D}\right),
$$

the age, $t$, of the sample is calculated to be $23.4 \pm 5.5$ $\mathrm{m} . \mathrm{y}$. The \pm figure is an estimate of the analytical precision at the 68 per cent confidence level, based on uncertainties in the corrections for the interfering argon isotopes derived from calcium and potassium, and on the amount of atmospheric ${ }^{40} \mathrm{Ar}$ in the sample, which was 91 per cent of the total ${ }^{40} \mathrm{Ar}$.

\section{EMPLACEMENT OF THE ROCKS}

Magmatic-arc rocks that intrude older, deformed trench and trench-slope deposits, and which are anomalously close to oceanic trenches, occur at several other places in the world, for example, at Sumatra, Kodiak Island, and Shikoku (Marshak and Karig, 1977). Following is a list of mechanisms that may be considered to explain the emplacement of such rock associations:

1. Magma leaks up the subduction zone to a neartrench discharge point (Hill and Morris, 1977). 


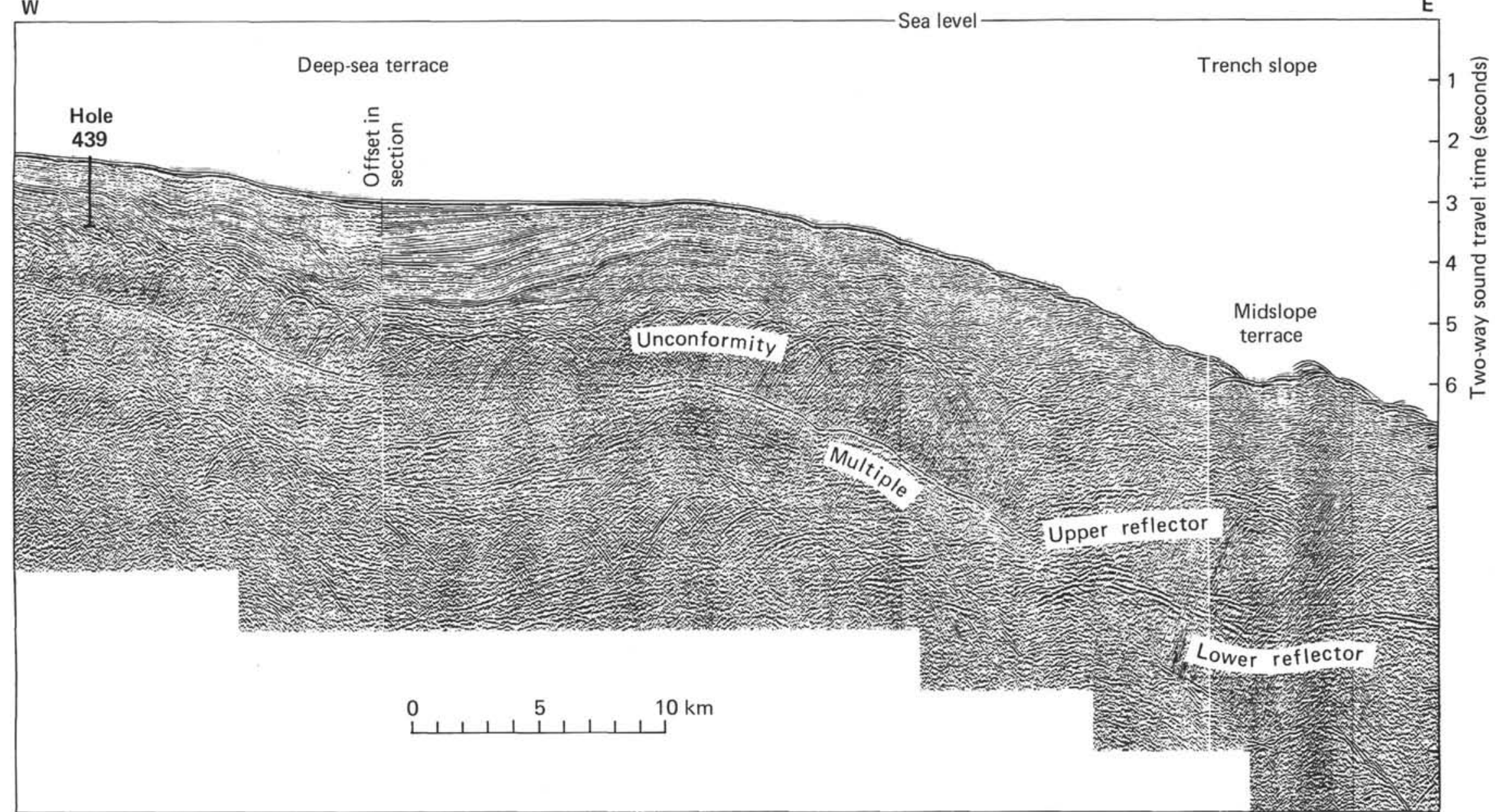

Figure 2. Reflectors below the deep-sea terrace and trench slope near the Japan Trench, showing the unconformity directly overlain by dacite conglomerate at the base of Hole 439. The unconformity, which separates Upper Cretaceous from middle-Tertiary rocks, can be traced to the midslope terrace, where it is underlain by two conspicuous reflectors, the lower of which is believed to be the subducting igneous crust. Multichannel Seismic Line is JNOC-1 (see Nane et al., this volume). 


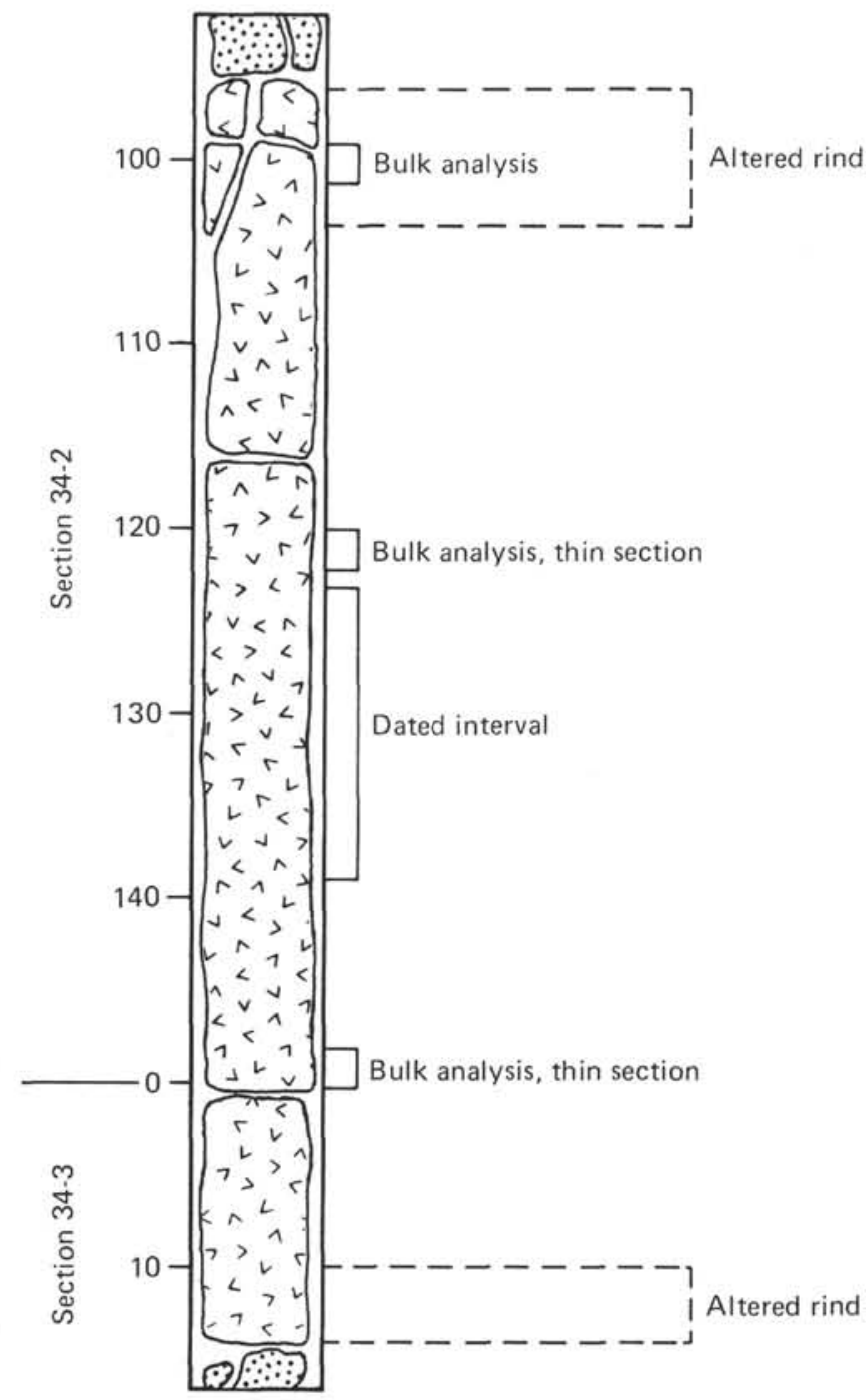

Figure 3. Sketch of the dated dacite boulder in DSDP Hole 439, showing positions of bulk chemical analyses, thin sections, and the dated interval. Scale in centimeters.

TABLE 1

X-Ray-Fluorescence Bulk Analysis of Samples from the Dated Dacite Boulder, Section 439-34-2, on a Water-Free, Weight-Percent Basis a

\begin{tabular}{lccc}
\hline Component & 99 to $101 \mathrm{~cm}$ & 120 to $122 \mathrm{~cm}$ & 148 to $150 \mathrm{~cm}$ \\
\hline $\mathrm{SiO}_{2}$ & 65.63 & 64.03 & 64.22 \\
$\mathrm{TiO}_{2}$ & 0.37 & 0.39 & 0.39 \\
$\mathrm{Al}_{2} \mathrm{O}_{3}$ & 23.47 & 20.29 & 20.59 \\
$\mathrm{Fe}_{2} \mathrm{O}_{3} \mathrm{~b}$ & 1.63 & 3.62 & 3.69 \\
$\mathrm{MnO}$ & 0.03 & 0.04 & 0.04 \\
$\mathrm{MgO}$ & 0.44 & 1.31 & 1.41 \\
$\mathrm{CaO}$ & 3.62 & 4.74 & 4.85 \\
$\mathrm{Na} 2 \mathrm{O}$ & 3.69 & 4.39 & 3.77 \\
$\mathrm{~K}_{2} \mathrm{O}$ & 1.04 & 0.99 & 0.97 \\
$\mathrm{P}_{2} \mathrm{O}$ & 0.09 & 0.20 & 0.06 \\
\hline
\end{tabular}

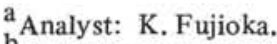

$b_{\text {Total }} \mathrm{Fe}$ as $\mathrm{Fe}_{2} \mathrm{O}_{3}$.
2. The plate boundary subducts an active sea-floorspreading ridge (Uyeda and Miyashiro, 1974).

3. The upper plate moves over a magmatic source from a second arc at a triple junction or at a cusp between arc segments (Marshak and Karig, 1977).

4. The subduction zone steps seaward, and heat from the old, lower plate melts the former trench sediment (Hudson and others, 1977).

5. The subduction zone steps rapidly seaward, establishing a new trench and line of volcanoes; the upper plate then overrides the volcanic source and carries the new magmatic rocks toward the trench. This requires consumption of material at the front of the overriding plate at the trench.

6. The subduction zone steps seaward, and at a later time it steps landward again, leaving magmatic rocks from the former stage anomalously near the trench. This too requires tectonic erosion of upper-plate rocks, probably by subduction.

The locality of the 23-m.y. dacite in Hole 439, part of a coarse-grained conglomerate that must have been deposited near its source area, lines up with a belt of granitic and granodioritic plutons that extends northward from Erimo Point across Hokkaido (Figure 1). Eight $\mathrm{K}-\mathrm{Ar}$ ages on these plutons range from 16 to $36 \mathrm{~m}$.y. (Nozawa, 1975). Because of the alignment and matching age of the dacite at Hole 439 with the middle-Tertiary plutonic belt on Hokkaido, we consider that all these magmatic rocks had a common origin. If this is correct, several of the genetic models on the foregoing list may be eliminated.

The middle-Tertiary plutons on Hokkaido trend approximately at right angles to the Kuril Trench and cross behind the line of the Kuril volcanoes. This relationship weakens the first three models, which do not involve stepping of the subduction zone. Model 1, the leaking subduction zone, can be rejected, because the anomalous igneous rocks would be expected to lie entirely seaward of both the Kuril and Japan volcanic arcs. Model 2 , the subduction of a sea-floor-spreading ridge, may not be compatible either, because the anomalous magmatism might be expected to follow along the two arc segments, and not to cross behind the volcanoes of the Kuril arc. Model 3, the movement of a trench area over an adjacent volcanic-arc segment, also seems to be eliminated, because a magmatic track left near the Japan Trench by the Kuril volcanoes should end at the present volcanoes and not pass beyond them.

Within the framework of the present evidence, each of the three models that involves stepping of the subduction zone could be compatible with the anomalous line of magmatic rocks. In all of them, a middle-Tertiary magmatic arc parallel to the Japan Trench extended beyond the present Kuril arc toward Sakhalin (Murauchi et al., 1973).

We favor Model 6 (Figure 4). During the Cretaceous, a plate boundary extended from Honshu through Sakhalin and around the north margin of the Bering Sea (Scholl and Buffington, 1970; Den and Hotta, 1973). 
TABLE 2

Electron-Probe Microanalysis of Individual Hornblende Phenocrysts, in Weight Percent, Section 439-34-2

\begin{tabular}{lrrrrrr|rrrr}
\hline Component & \multicolumn{5}{c|}{120 to $122 \mathrm{~cm}$} & \multicolumn{3}{c}{148 to $150 \mathrm{~cm}$} \\
\hline $\mathrm{SiO}_{2}$ & 46.15 & 45.06 & 46.06 & 45.53 & 46.97 & 44.47 & 46.43 & 44.00 & 42.23 & 42.32 \\
$\mathrm{TiO}_{2}$ & 1.47 & 1.68 & 1.47 & 1.36 & 1.43 & 1.63 & 1.08 & 1.55 & 1.32 & 1.58 \\
$\mathrm{Al}_{2} \mathrm{O}_{3}$ & 8.18 & 8.21 & 11.31 & 8.40 & 8.72 & 10.05 & 10.18 & 9.91 & 9.88 & 10.10 \\
$\mathrm{FeO}^{\mathrm{a}}$ & 7.62 & 9.24 & 7.62 & 9.16 & 10.05 & 10.15 & 7.83 & 10.33 & 8.13 & 7.43 \\
$\mathrm{MnO}$ & 0.11 & 0.14 & 0.07 & 0.14 & 0.18 & 0.18 & 0.04 & 0.11 & 0.16 & 0.07 \\
$\mathrm{MgO}$ & 16.97 & 17.02 & 15.56 & 16.96 & 16.40 & 16.11 & 17.08 & 15.72 & 14.83 & 15.35 \\
$\mathrm{CaO}$ & 11.17 & 10.69 & 11.24 & 11.47 & 10.91 & 11.06 & 10.58 & 10.28 & 9.71 & 10.48 \\
$\mathrm{Na} 2 \mathrm{O}$ & 2.81 & 3.03 & 2.45 & 2.74 & 2.94 & 2.90 & 2.74 & 3.38 & 3.13 & 2.95 \\
$\mathrm{~K}_{2} \mathrm{O}$ & 0.18 & 0.15 & 0.16 & 0.16 & 0.14 & 0.15 & 0.06 & 0.04 & 0.12 & 0.14 \\
\hline
\end{tabular}

${ }^{\mathrm{a}}$ Total Fe as FeO.

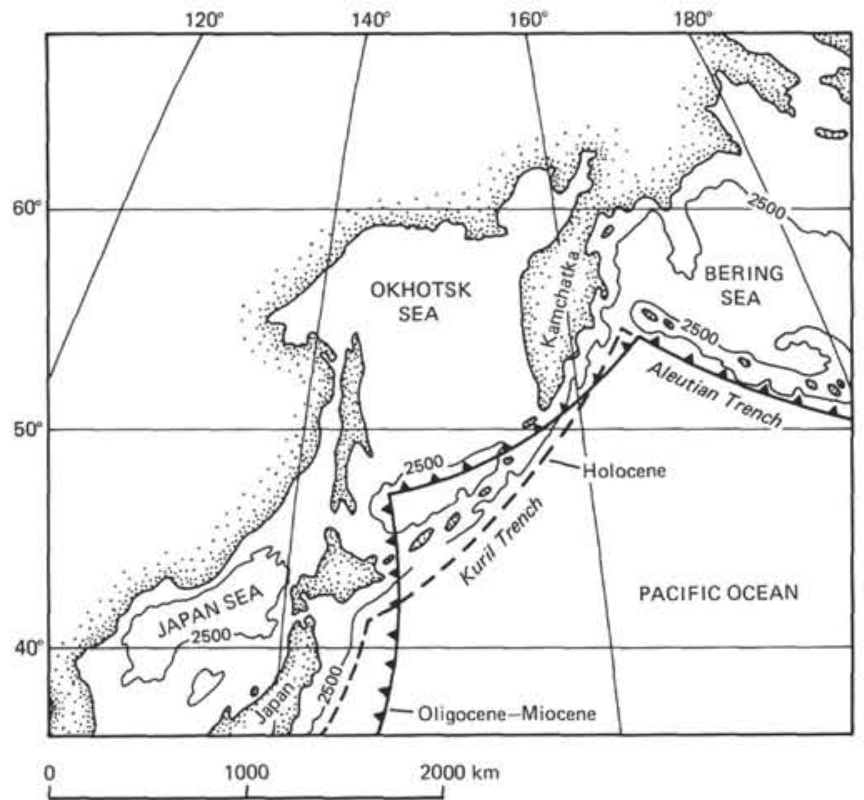

Figure 4. At the Oligocene/Miocene boundary, magmatic rocks are inferred to have been produced along a subduction zone that was east of the present Japan subduction zone and north of the Kuril.

During this period, the extensive Cretaceous batholiths of Honshu and western Hokkaido were emplaced.

Approximately by Paleocene time, the plate boundary had stepped out to the Aleutian arc; in the west, it lay along the Pacific coast of Kamchatka. The alignment during this period was slightly different from the present alignment. West of where it extended around Kamchatka, the plate boundary passed on the north side of the deep part of the Okhotsk Sea, beyond which it turned south and passed east of Hokkaido, and slightly east of the present Japan Trench (Figure 4). During this period, the dacite encountered at Site 439 probably was erupted, and the plutons were emplaced on Hokkaido.

Finally, during the Miocene, the subduction zone stepped to its present position. The magmatic arc across Hokkaido was abandoned, and the Kuril arc came into existence. At that time, the Japan Trench took its present position, and the dacite at Site 439 began to subside and become covered by basinal deposits.
This model requires that Miocene to Holocene subduction has removed a former trench system that lay seaward from the modern Japan Trench. We know that the Japan Trench is now subducting sediment deeply, because the wedge of deformed strata under the lower part of the trench slope is too small to account for the oceanic sediment that the Pacific plate has brought in during the past $16 \mathrm{~m} . \mathrm{y}$. (see Site 434 and Site 441 reports, this volume). At a local convergence rate of 10 $\mathrm{cm}$ per year (present-day value; Minster and Jordan, 1978), and an average sediment thickness of 200 meters, a cross-sectional area of $320 \mathrm{~km}^{2}$ perpendicular to the trench is delivered in $16 \mathrm{~m} . \mathrm{y}$. The triangular section of the wedge of deformed sediment under the lower trench slope has an area of only $70 \mathrm{~km}^{2}$, however, indicating that possibly more than three-fourths of the oceanic sediment has been deeply subducted. The convergence rate may not have been this rapid throughout the Neogene. Perhaps Paleocene to Oligocene plate convergence also subducted, rather than accreted, most oceanic sediment, so that the near-surface accreted wedge seaward from the present trench was relatively small when the subduction zone stepped toward Japan.

\section{ACKNOWLEDGMENTS}

We are indebted to G. Brent Dalrymple for help in obtaining and interpreting the radiometric date. The manuscript was reviewed by Tracy L. Vallier and William R. Dickinson.

\section{REFERENCES}

Dalrymple, G. B., and Lanphere, M. A., 1971. ${ }^{40} \mathrm{Ar} / 39 \mathrm{Ar}$ technique of $\mathrm{K}-\mathrm{Ar}$ dating: a comparison with the conventional technique. Earth Planet. Sci. Lett., 12, 300-308.

Den, N., and Hotta, H., 1973. Seismic refraction and reflection evidence supporting plate tectonics in Hokkaido. $\mathrm{Pa}$ pers Meteorol. Geophys., 24, 31-54.

Dickinson, W. R., 1973. Widths of modern arc-trench gaps proportional to past duration of igneous activity in associated magmatic arcs. J. Geophys. Res., 78, 3376-3389.

Hill, M. D., and Morris, J. D., 1977. Near-trench plutonism in southwestern Alaska. Geol. Soc. Am. Abs. Programs, 9, 436-437.

Hudson, T., Plafker, G., and Lanphere, M. A., 1977. Intrusive rocks of the Yakutat-St. Elias area, south-central Alaska. U.S. Geol. Surv. J. Res., 5, 155-172. 
Marshak, R. S., and Karig, D. E., 1977. Triple junctions as a cause for anomalously near-trench igneous activity between the trench and volcanic arc. Geology, 5, 233-236.

Minster, J. B., and Jordan, J. H., 1978. Present-day plate motions. J. Geophys. Res., 83, 5331-5354.

Murauchi, S., Asanuma, T., and Ishii, H., 1973. Geophysical studies on the sea around Hokkaido. Natl. Sci. Mus. J., 6, 163-182.
Nozawa, T., 1975. Radiometric age map of Japan; granitic rocks. Geol. Surv. Japan Map Ser., 16-1, 1:2,000,000.

Scholl, D. W., and Buffington, E. C., 1970. Structural evolution of Bering continental margin: Cretaceous to Holocene. Am. Assoc. Petrol. Geol. Bull., 54, 2503.

Uyeda, S., and Miyashiro, A., 1974. Plate tectonics and the Japanese Islands: a synthesis. Geol. Soc. Am. Bull., 85, 1159-1170. 